\title{
Research on Database Principle and Application Course Reform Based on the Talent Training Mode of School-enterprise Cooperation
}

\author{
Lu Wang \\ School of Mathematics and Information Engineering \\ Chongqing University of Education \\ Chongqing 400065 China \\ wanglu514@163.com
}

\begin{abstract}
School enterprise cooperation, the talents training mode, not only meets the needs of China's economic and social development, but also suits talent training in higher education institutions. Therefore, it is an effective teaching method for local universities to realize the cultivation of applied talents. This paper, based on the school enterprise cooperation, studies the training model of the applied talents in local universities database. The article discusses how to build talent training program of school enterprise cooperation; and under the new teaching model, the reform of the database course construction, teaching methods, and the teaching group. In this way, we can achieve a clear understanding of student learning objectives, mobilize the students, and cultivate students' work ability and professional quality, which has certain reference significance for the training of database application talents.
\end{abstract}

Keywords-school enterprise cooperation; talent training; database; curriculum reform

\section{INTRODUCTION}

As an independent school of $2^{\text {nd }}$ class, our school focuses on training applied talents with practical abilities. The cooperation between schools and enterprises is a new type of teaching model, which can not only realizes the combination of production and learning, but also cultivates talents with practical ability according to the needs of society. As the social economy continues to advance, people's living standards have been improved, and the competition among enterprises has become fierce. In order to improve the competitiveness of enterprises, and enable students to adapt to work better and faster, schools and enterprises cooperate in running schools so as to train students jointly. The project team introduced the database courses into the enterprise, allowing students to understand the overall flow of the development database project and the latest database development technology, so that students can learn the database theory and application in the actual project of the enterprise. School-enterprise cooperation enables schools and enterprises to help and support each other. The combination of teaching resources and corporate resources will surely cultivate high-quality applied talents according to the actual needs of the company. The school-enterprise

Fund Project: Chongqing University of Education Teaching Reform Project: Research on Database Principle and Application Course Reform Based on the Talent Training Mode of School-enterprise Cooperation (Project Number JG201731) cooperation will benefit the school and the company, except that, the company can formulate student training programs in conjunction with the school on the basis of social needs. Schools can also invite technical experts in the enterprise to the classroom to guide students in practical courses and impart the latest database development technology to students, and let students understand the work process of enterprise project, so that the focus of learning can be more clearly defined and students' practical ability and project awareness can be improved.

\section{REFORM OF SCHOOL-ENTERPRISE COOPERATIVE TALENT TRAINING MODE}

In 2016, our school started the training mode cooperated by schools and enterprises and signed with ZTE Corporation on the order form classes, namely "ZTE Cloud Computing" and "ZTE Mobile Internet". In response to the needs of ZTE Corporation, we have developed different talent training programs for different majors.

The design concept of the training program is to grasp the requirements, refer to standards, accord with posts, center on capacity, build extension map of talent training, restructure the curriculum system, and construct a three-loop hyperbolic personnel training model. It takes market demand as guidance, and application skills development as a goal, builds a progressive practice teaching system to comprehensively improve the core competitiveness of student in employment.

Through cooperative teaching with enterprises, our school has developed a profession training program and implemented A and B credit course systems. A credit targets for different ability to set curriculum, as shown in Table 1 below. B credit mainly focuses on students' quality education, professional application ability and other aspects. 
TABLE I. Course SetTing

\begin{tabular}{|c|c|c|c|c|}
\hline Ability & \multicolumn{3}{|c|}{ Course } & Proportion \\
\hline \multirow{4}{*}{ General ability } & \multirow{2}{*}{$\begin{array}{l}\text { Compulsory } \\
\text { course }\end{array}$} & Basic general course & & \multirow{4}{*}{$30 \%$} \\
\hline & & \multicolumn{2}{|c|}{ Course with corporate characteristics } & \\
\hline & \multirow{2}{*}{ Elective course } & \multicolumn{2}{|c|}{ Exploratory course } & \\
\hline & & \multicolumn{2}{|l|}{ Special course } & \\
\hline $\begin{array}{ll}\begin{array}{l}\text { Basic } \\
\text { ability }\end{array} & \text { professional } \\
\end{array}$ & \multicolumn{3}{|c|}{ Basic compulsory course } & $20 \%$ \\
\hline \multirow{5}{*}{ Core competency } & \multicolumn{3}{|c|}{ Professional core course } & \multirow{5}{*}{$40 \%$} \\
\hline & \multirow{4}{*}{$\begin{array}{c}\text { Individual } \\
\text { development } \\
\text { course }\end{array}$} & \multicolumn{2}{|c|}{ Major elective course } & \\
\hline & & Professional course & \multirow{3}{*}{$\begin{array}{l}\text { One out of } \\
\text { three }\end{array}$} & \\
\hline & & $\begin{array}{l}\text { Innovation and } \\
\text { entrepreneurship course }\end{array}$ & & \\
\hline & & Research course & & \\
\hline \multirow{3}{*}{$\begin{array}{l}\text { Professional } \\
\text { comprehensive ability }\end{array}$} & \multicolumn{3}{|c|}{$\begin{array}{l}\text { Periodic comprehensive ability training (probation, project } \\
\text { training) }\end{array}$} & \multirow{3}{*}{$10 \%$} \\
\hline & \multicolumn{3}{|c|}{$\begin{array}{c}\text { Graduation comprehensive ability training (internship, graduation } \\
\text { design, graduation thesis) }\end{array}$} & \\
\hline & \multicolumn{3}{|c|}{ Research-orientated, innovative comprehensive ability training } & \\
\hline
\end{tabular}

A. Building three-cycle hyperbolic talents cultivation model and achieving "five objectives" of talents through threewheel drive

Taking the transformation of the overall technical skills of our institute as an opportunity, we highlight the application and comprehensive transformation and build a three-cycle hyperbolic talents cultivation model. The three-wheel drive has achieved five objectives of talents cultivation, namely, "keeping up with technology, being able to say the process and do projects, enduring the loneliness, integrating into the team". The frame diagram is shown in figure 1 below.

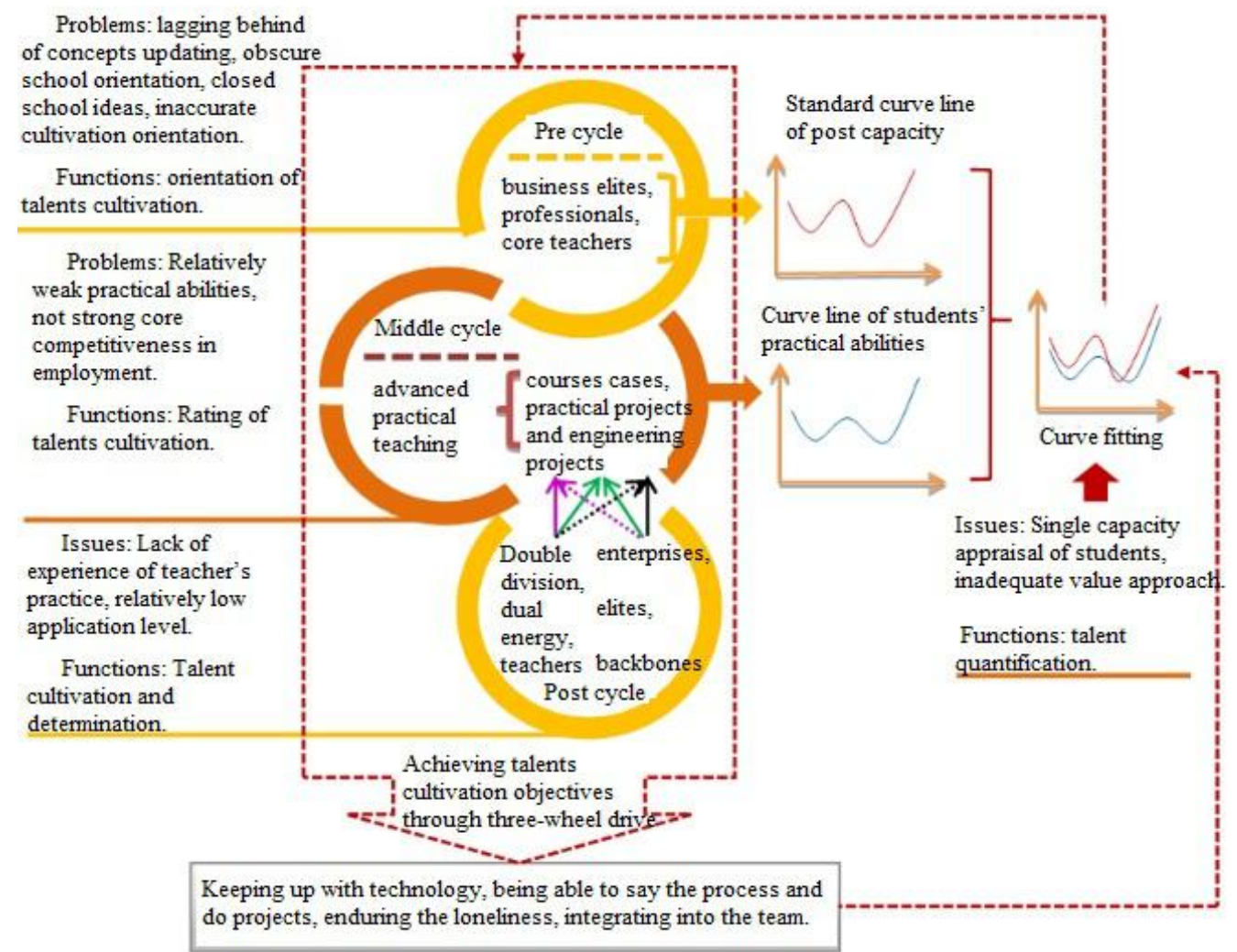

Fig. 1. Frame diagram of school-enterprise cooperative talents cultivation 


\section{B. Guided by the market demand, portray the position standard ability}

In the "pre cycle", we avoid "structural unemployment" through extensive research on the skills requirements of talents for local industrial development, the post qualification standards are compiled from the industry, training plans are developed according to post competence standards, and they are converted to training content, and finally the post competence standard curve is obtained and has laid a solid foundation for the training of skilled technicians.

\section{Targeting the cultivation of applied ability, building a step-by-step progressive practice teaching system to comprehensively improve the core competitiveness of student employment}

"Centralization cycle" is the core of technical and technician talents cultivation. Practical teaching is the key to achieving the goal of training technical and skilled talents. It is also a difficult point for the transformation of technical and skilled talents. The step-by-step practice teaching system is centered on a technical main line, adheres to the "specialty plus strong points" talents cultivation specifications, and focuses on cultivating students' three-level capabilities of "basic skillscore skills - innovation and entrepreneurship".

\section{APPLICATION-ORIENTATED PERSONNEL TRAINING OF LOCAL UNIVERSITIES DATABASE BASED ON THE UNIVERSITY- ENTERPRISE COOPERATION}

\section{A. Designing course positions and optimizing teaching content}

The project team takes the changes in the human resource requirements of the industry as the orientation, and designs and optimizes the training objectives and requirements of related database courses through the extensive research and stratification of industries, occupations, work content and tasks, professional competence and quality. They also formulate professional database personnel training programs and teaching content that meet the needs of industry development and employment, so as to achieve the overall optimization of the top-level design of the cooperative professional.

Through this course, students can master the basic concepts of the relational database theory and database management system and the basic rule of the database, so as to skillfully run the basic operations of the database. The main contents of the course are as follows, the basic principles of relational databases, database management, table management, data query, index and view, data integrity, stored procedures and triggers, database security management, database backup and restore, database application system development, etc.

The project team adopts the teaching mode of CDIO, namely Conceive, Design, Implementation, and Operate. They work with the experts of the company to find the jobs that are related to the database course, and according to different job requirements, make different training plans. The training projects will be designed according to the actual work process of the company, allowing the projects running through the whole theoretical and practical teaching process.

\section{B. Make innovations in teaching methods to improve teaching quality}

In the teaching method reform, we build a training environment that integrates industry experience, job skills practice, and engineering project drill. The database course system focuses on the needs of the industry market and centers on competence training. Together with it, we combine projectbased teaching methods to deliver high quality database course efficiently, promote the reform of teaching and training mode, and finally realize the cultivation of database applicationoriented technical personnel.

The teaching database professional courses are undertook jointly by school and enterprise teaching staff. In the teaching process, teaching methods such as MIMPS teaching method and engineer independent teaching which are suitable for practical personnel training are adopted together with the project-based teaching and group confrontation teaching, giving full play to the experience of corporate lecturers.

As for MIMPS teaching mode, $M$ refers to Modularization; I refers to Interlacement; $\mathrm{M}$ refers to Mission; $\mathrm{P}$ refers to Practical-research; S refers to Self-evaluation. Through the project division method, the database curriculum content is integrated into a series of tasks. The students play the roles of employees in the task to experience the actual work, and are guided to think actively, discuss in groups and self-evaluate by the setting of research-based training topics in a bid to enable students to understand theoretical knowledge, master practical skills and cultivate professional qualities, thus increasing interest in learning and promoting teaching quality.

As for engineer independent teaching, the job skills requirements and professional quality requirements of the database industry are closely linked. The lecturer will play free according to the characteristics of his industry, and will carry various forms of lectures such as actual case teaching, independent student research, and task drills to pass on engineering project experience and the work methods of the company.

\section{Cultivate teachers and optimize teaching group}

In the curriculum reform, with a variety of teaching and research activities such as joint teaching, collaborative lessonplanning, visiting class, observing trial teaching, internal training, joint innovation in teaching methods and exchange of teaching experiences, the practical teaching capabilities of college teachers have been gradually improved. College teachers through the participation of business practice and engineer training improve job ability cognition, teaching level, experimental equipment operation level, achieve the combination of learning and work, thereby becoming the "double-qualified" teachers and constantly optimize the structure of the teaching staff.

The cooperation also hired experts from the company as instructors for database courses. Experienced project managers, senior engineers, and technical experts who are from ZTE Corporation work as professional lecturers for collaborative database courses. 


\section{Develop teaching resources and build a practical training environment}

The cooperation utilizes the teaching resources and the industry resources, and adjusts database curriculum structure, recognizes curriculum relations, optimizes teaching content, and enriches curriculum resources such as teaching materials, courseware, videos, engineering cases, and online resources, and finally builds a scientific and content-optimized curriculum system that meets the actual needs of cultivating modern, highquality and innovative talents.

In the training laboratory construction, the frontier database technology was introduced into the university practice teaching system, and a new type of database laboratory with various functions such as industry experience, visiting and observation, project practice, and operation and training was built to fully promote the integration and development of practical teaching ability and innovative service capability of the database.

\section{CONCLUSION}

Based on the university-enterprise cooperation, the reform of the applied talents in the database of local universities and colleges, through the guidance of students in career planning, simulate an atmosphere for students to learn and grow in the enterprise. The company conducts targeted job skills training for students, passes corporate culture and quality required by related positions to schools, integrates with campus culture, improves the pertinence and effectiveness of quality education in schools, and enhances students' professional ability and quality to achieve high-quality employment with highly efficient personnel training.

School enterprise cooperation enables the school to make innovation in applied talents training model by relying on the industrial advantages of the enterprise, increase the construction level of database professional courses, and improve teachers' scientific research and technical service capabilities.
Enterprises and school teachers jointly formulate and improve talent training programs, conduct teaching, and build and maintain practical teaching platform. They also jointly develop and optimize teaching materials and resources, establish teaching resource database, participate in teaching seminars and activities, and comprehensively improve teachers' engineering experience, practical operating skills and teaching business capabilities so as to improve the quality of applied talents.

\section{REFERENCES}

[1] Du Yao. Network Database Technology Curriculum Reform Based on School-enterprise Cooperation, Work-integrated Learning Talent Cultivation Model.2012(03):25-27,31

[2] Yu Yisheng. Reform of Higher Vocational Database Application Course Based on Cooperation between School and Enterprise[J].Journal of Xiangyang Vocational and Technical College.2016(09):9-11

[3] Wang Xiujuan. Research on the Training of Database Course Innovation Practice Ability under the Cooperation of "3+1" School-enterprise Cooperation [J]. China Modern Educational Equipment.2014(01):60-61

[4] Tang Junfang. The Application Reform of "Database Development Technology" Course in College-Enterprise Cooperation [J]. Journal of Zhejiang Shuren University(Acta Scientiarum Naturalium).2013(06)

[5] Wang Xianghui, Cui Wei, Xu Junli. Research on Database Course Teaching Reform Scheme Based on CDIO [J]. Computer Education.2011(02):38-41

[6] Wang Wenjun, Deng Jingshun, Wang Jing. Research on Teaching Mode of Database Course System Based on Computational Thinking [J]. Journal of Linyi University.2014(06)

[7] Liu Jing,Tian Xuezhi. Development and Practice of School-Enterprise Cooperative Curriculum Based on the Demand of Professional Ability [J].Science and Technology Innovation Herald.2012(14)

[8] Lan Bo. The Implementation of Project Teaching Method in the Teaching of "SQL Server Database" Course [J].Education Forum.2012(26)

[9] Sun ping'an. Application of Project Task-driven in Database Course Teaching [J]. Journal of Langfang Teachers University ( Natural Science Edition) .2012(04) 